\title{
Improving the Governance of New Zealand's State-Owned Enterprises
}

\author{
Jim Brumby, Michael Hyndman and Stuart Shepherd
}

D ESPITE substantial divestments in recent years, the New Zealand central government continues to own a range of commercial businesses, most of which form part of the state-owned enterprises (SOE) portfolio.

An economic case may be made for privatising more SOEs. However, the present National-New Zealand First coalition government has indicated that it intends to retain ownership of at least some of them. This political stance is not unusual internationally, and raises the interesting issue of how the governance of these commercial businesses can be structured within the context of continued government ownership. This article explores the nature of this governance issue, and recommends a set of policies to address it.

The core difference between state and private ownership, from a governance perspective, concerns the rights, obligations and pay-offs attaching to ownership. Private ownership confers extensive rights on the owner to enjoy the income from ownership, and to control and change the use to which resources are put, including transferring ownership to another party. The private owner faces directly the wealth consequences from exercising those rights, and therefore has greater reason to ensure that they are put to best use.

Government ownership, in contrast, confers only a very limited set of rights on the ostensible owner or shareholder (in New Zealand, the shareholding Ministers). The shareholder has limited powers to control or change the use to which a resource is put, and, in particular, is not empowered to transfer ownership of SOE shares without parliamentary consent. The shareholder does not face any direct wealth consequences from exercising those rights, but is likely to face significant political costs or benefits from doing so.

\footnotetext{
${ }^{1}$ The Coalition Agreement of 10 December 1996 stipulates that five SOEs - ECNZ, Contact Energy, Trans Power, New Zealand Post, and part of TVNZ (TV1) - are to be considered 'strategic' and are not for sale.
}

Jim Brumby is Head of Programme, Public Sector Management Service, OECD, Paris; Michael Hyndman is Chief Analyst, Asset and Liability Management Branch, New Zealand Treasury; and Stuart Shepherd is Manager, Integrated Costing and Economics Group, Telecom New Zealand Limited. The views expressed in this article are the authors' and not necessarily those of their employers. 
Many commentators conclude that these differences in the nature of ownership illustrate the need, from an economic efficiency perspective, to move as much commercial activity as possible into private ownership. We agree with that conclusion. However, governments continue in practice to own commercial businesses, and it is in this context that this article addresses $\mathrm{SOE}$ governance issues.

\section{Background to New Zealand's SOEs}

Corporatisation and privatisation history. Prior to the creation of SOEs, government-owned businesses in New Zealand were largely operated within various departments whose functions also included advising the government on policy issues. This situation entailed frequent ministerial involvement in their operations; multiple, sometimes unclear and often conflicting goals (such as employment creation and profitability); and thus unclear accountability. Their transformation into SOEs through corporatisation resulted in a clear commercial focus, and greatly improved accountability arrangements. Since 1989 the government has privatised 13 SOEs for a total sale price of NZ $\$ 9.1$ billion, in the context of 31 significant sales of government assets with a total sale price of NZ\$15.9 billion.

SOEs remain a major component of both the central government's balance sheet and the wider economy. As at 30 June 1997 their total assets of NZ\$10.3 billion comprised about 18 per cent of the book value of total assets controlled by all government entities. Their total revenue equated to about 4 per cent of GDP. They are involved in a diverse range of business activities, including electricity generation and transmission, provision of postal and meteorological services, coal and forestry production, farming and office accommodation, and air traffic control. How SOEs use the resources under their control therefore has a major impact on New Zealand's economic performance (see Table 1).

SOE governance arrangements. Each SOE is formed as a company under the Companies Act 1993 and is subject to its general provisions. In addition, each SOE must comply with specific governance and accountability provisions under the State Owned Enterprises Act 1986. The Act sets each SOE the primary goal of being 'a

\footnotetext{
${ }^{2}$ Megginson et al. (1994) found strong performance improvement from privatisation in a study of 61 privatised companies in 18 countries. Vining and Boardman (1992) found privately owned firms tend to out-perform their state-owned counterparts. Galal et al. (1995) showed, in a sample of twelve privatisations in four countries, that net welfare increased in eleven of the cases. Domberger and Piggott (1994:56) argue that 'the case for privatisation rests on the incentives and constraints that the market provides to promote Iproductivel efficiency within the firm'. They found the empirical evidence, however, provided inconclusive support for privatisation. A World Bank (1996:49) report found that the gains from privatisation and other related reforms are substantial, although only a few countries have reformed their SOEs successfully. Vickers and Yarrow (1991) emphasise that the effects of privatisation in any particular context will depend significantly on the wider market, regulatory and institutional environments in which it is implemented.

${ }^{3}$ These figures sourced from the New Zealand Treasury are as at 30 June 1997.
} 
successful business', and defines this as being as profitable as a comparable business not owned by the Crown, as well as being a good employer and socially responsible. SOE voting shares may not be sold without parliamentary approval. All SOEs are 100 per cent government owned, with the voting shares held equally by the two shareholding ministers: the Minister of Finance and the 'responsible Minister' (who by convention is normally the Minister for State Owned Enterprises).

\section{Table 1}

Summary financial data of SOEs as at 30 June $1997^{\mathrm{a}}$

\begin{tabular}{|c|c|c|c|c|c|c|}
\hline \multirow[t]{2}{*}{$\begin{array}{l}\text { State-owned } \\
\text { enterprise }\end{array}$} & \multirow{2}{*}{$\begin{array}{l}\text { Total } \\
\text { revenue } \\
N Z \$ m\end{array}$} & \multirow{2}{*}{$\begin{array}{l}\text { Operat- } \\
\text { ing sur- } \\
\text { plus } \\
N Z \$ m\end{array}$} & \multirow{2}{*}{$\begin{array}{l}\text { Total as- } \\
\text { sets (book } \\
\text { value) } \\
\text { NZ\$m }\end{array}$} & \multirow{2}{*}{$\begin{array}{l}\text { Equity } \\
\text { (book } \\
\text { value) } \\
\text { NZ\$m }\end{array}$} & \multicolumn{2}{|c|}{$\begin{array}{c}\text { Percentage of } \\
\text { total equity } \\
\text { cum. }\end{array}$} \\
\hline & & & & & $\%$ & $\%$ \\
\hline ECNZ & 1,142 & 271 & 3,608 & 2,084 & 36.9 & 36.9 \\
\hline Trans Power & 550 & 92 & 2,960 & 1,384 & 24.5 & 61.4 \\
\hline Contact Energy & 478 & 83 & 1,455 & 862 & 15.3 & 76.7 \\
\hline Land Corp & 68 & 10 & 487 & 412 & 7.3 & 84.0 \\
\hline TVNZ & 469 & 55 & 495 & 254 & 4.5 & 88.5 \\
\hline NZ Post & 678 & 53 & 468 & 179 & 3.2 & 91.7 \\
\hline $\begin{array}{l}\text { Govt. Property } \\
\text { Services }\end{array}$ & 32 & 29 & 282 & 178 & 3.2 & 94.9 \\
\hline CoalCorp & 209 & 18 & 196 & 116 & 2.1 & 97.0 \\
\hline $\begin{array}{l}\text { Timberlands West } \\
\text { Coast }\end{array}$ & 28 & -12 & 114 & 111 & 2.0 & 99.0 \\
\hline $\begin{array}{l}\text { Airways Corpora- } \\
\text { tion }\end{array}$ & 94 & - & 168 & 40 & 0.7 & 99.7 \\
\hline $\begin{array}{l}\text { Meteorological } \\
\text { Service }\end{array}$ & 24 & 4 & 14 & 11 & 0.2 & 99.9 \\
\hline $\begin{array}{l}\text { Vehicle Testing } \\
\text { NZ }\end{array}$ & 21 & 3 & 13 & 7 & 0.1 & 100.0 \\
\hline Terralink & - & -7 & 16 & 7 & - & \\
\hline $\begin{array}{c}\text { NZ Railways } \\
\text { Corp }\end{array}$ & 2 & - & 9 & 1 & - & \\
\hline $\begin{array}{c}\text { Works and De- } \\
\text { velopment }\end{array}$ & - & 33 & - & - & - & \\
\hline Total & 3,795 & 632 & 10,285 & 5,646 & 100.0 & 100.0 \\
\hline
\end{tabular}

Notes: ${ }^{a}$ The revenue and surplus figures are for the year to 30 June 1997 . ${ }^{b}$ Not an operating company.

Source: Financial Statements of the Government of New Zealand for the year ended 30 June 1997, Wellington, New Zealand, 1997, pp. 91-3 n.9.

Shareholding ministers hold the formal rights to appoint SOEs' directors, determine their constitutions, and appropriate (on behalf of government) their residual earnings plus residual assets if they are wound up. The Companies Act requires the directors of an SOE to act in good faith in what they believe to be in the best interests of the company.

The SOE Act requires each SOE board to provide the shareholding ministers an annual Statement of Corporate Intent (SCI) setting out the scope of business of 
the SOE, along with its broad goals and specific performance targets. The shareholding ministers monitor the performance of the SOE and its board of directors. The Act also permits the shareholding ministers to direct an SOE board to include particular items in the SCI or omit them from it. Use of this power is subject to parliamentary scrutiny. Moreover, if the shareholding ministers direct an SOE to provide goods or services that it normally would not provide as part of a commercial arrangement, the SOE can require the government to compensate it for any resultant financial detriment.

SOEs are taxed in the same way as privately owned companies and are subject to the same set of commercial, safety and health regulations as other companies. They are able to raise debt in their own name, and this debt is explicitly not underwritten by the government.

Market and regulatory environment. The government has sought to create an $\mathrm{SOE}$ only where there is the prospect of competition in the markets for its products, or an effective regulatory regime is in place. Most of the existing SOEs do operate in markets which are already competitive or at least face the threat of competition. The exceptions fall into two categories: natural ${ }^{5}$ and statutory monopolies.

The national electricity transmission grid, which Trans Power owns and operates, is the only significant natural monopoly. ${ }^{6}$ This SOE is subject to a set of regulatory pricing constraints.

Two SOEs, NZ Post and the Airways Corporation, currently operate in product markets protected by statutory barriers to entry from other suppliers. No compelling economic reason appears to exist for these barriers to continue. Indeed, in NZ Post's case legislation has recently been introduced to the parliament which would remove the statutory barrier.

The governance policies recommended below assume the SOE is operating in a competitive product market. The statutory barriers to market entry are best viewed as transitory issues, leaving the issue of natural monopoly. The definition of 'core business' is one policy recommendation that may need to be tempered to take account of this (as elaborated below).

\section{Differences between Government and Private Ownership}

As mentioned above, the key differences between government and private ownership lie in the nature of the rights and obligations in the two cases, and how these differences affect incentives and decision making.

Under private ownership the owners typically have the right to income from the resources. The owners face directly the wealth effects from the way in which the

\footnotetext{
${ }^{4}$ This has happened on one occasion only.

${ }^{3}$ A 'natural monopoly' exists where output costs in a market for a particular product or its close substitutes are minimised when there is only one supplier.

${ }^{6}$ The Airways Corporation also has a natural monopoly in some of its markets, but changes in technology are reducing the extent of it.
} 
resources are used. They also have the right to control and change the manner in which the resources are used, ${ }^{7}$ including the right to transfer ownership to another party. The combination of the right to income and the right to control provides private owners with both the incentive and the ability to move their resources to their highest-value use. This approach to resource management lies at the heart of the allocation of capital within open market economies.

Under government ownership the shareholding ministers have the right to income on behalf of taxpayers. The shareholding ministers do not personally face any wealth effects from the way in which resources are used, but are likely to face political costs or benefits from decisions that they make in relation to how resources are deployed. They also have a more limited set of rights to control and change the manner in which the resources are used. Shareholding ministers are not able to transfer ownership without parliamentary approval, and any direction these ministers give to an SOE is subject to parliamentary scrutiny.

Government ownership breaks the nexus between personal wealth effects and the ability to control and change resource use. Instead, government shareholders can be expected to be concerned primarily with political (rather than economic) outcomes, and to have limited ability to effect change. For this reason, the allocation of capital under this arrangement is likely to be significantly less efficient than under private ownership.

These special features of the ownership structure of SOEs lead to a number of issues for the governance of these companies. First, they result in weak equity capital disciplines on the board and management. The absence of active trading in SOE shares, or of owners with a personal equity stake, weakens the discipline on these companies to maximise value. Furthermore, the constraints on the shareholders in relation to divestment remove any credible takeover threat that would otherwise face the board and management of an under-performing company. This weak discipline is likely to feed through to a tendency to operate less efficiently than otherwise would be the case, and to undertake projects that are not justifiable if allowance is made for the full opportunity cost of capital.

Second, they lead to weak debt-holder monitoring. Private debt holders have weak incentives to monitor an SOE's performance, to the extent they consider SOFs to be implicitly government guaranteed. Although all New Zealand SOE debt instruments are required to include an acknowledgment that the debt is not guaranteed by the government, the financial markets have seen little evidence of a New Zealand government being prepared to let any SOE fail financially. In cases of financial distress the government has provided additional equity or the promise of additional equity, rather than rely on its limited liability status to restrict its financial exposure. Nevertheless, the structure of debt capital obligations, which typically

\footnotetext{
${ }^{7}$ These rights are in practice constrained by a range of general legislative prohibitions on resource use, including for example the Resource Management Act.
} 
include specified cash payments throughout the life of the loan, can be expected to provide a greater financial discipline on SOEs than that afforded by equity capital.

Finally, the ownership structure of SOEs leads to less certainty and clarity about shareholder business policy commitments. Shareholding ministers' commitment to a particular set of business policy parameters governing an SOE's operation is likely to be seen as less certain than if such a commitment were issued by private shareholders. Private shareholders tend to be more focused on a single clear goal of improving the value of their business. SOE shareholders, in contrast, typically are likely to be influenced by multiple factors (such as changes of government and changes in electoral factors within an electoral term). ${ }^{10}$ Forecasting how such factors are likely to impact on SOE-related policies is more complex and uncertain than with private ownership.

\section{Focusing on Core Activities}

The remaining sections canvass policies to improve SOE governance from the perspective of a government concerned with the overall efficiency of the economy. This is a wider perspective than that held by the private shareholder, which is concerned only with improving the value of the entities it owns. This wider view results in policies that both improve the efficiency with which SOEs are governed ${ }^{11}$ and reduce the extent to which assets remain under SOE control (subject to constraints on privatisation), as there are alternative (private) governance arrangements that can be expected to yield more efficient results.

The policies fall into three groups: focusing the company on its core activities; strengthening financial disciplines; and managing the ongoing relationship between the government and SOEs. Focusing on core activities involves reducing the scale and scope of SOEs and changing their operating structures.

Reducing scale and scope. Reducing the scale and scope of SOEs over time can, if the resulting opportunities are taken up by privately owned firms, be expected to improve overall economic efficiency. A sharper focus can be achieved, in part, by: not extending an SOE's scope beyond a clearly defined set of core business activities or scale of operation (for example, by declining proposed expansions, even though the expected return may exceed the cost of extra capital required); divesting

\footnotetext{
8 Jensen (1986) outlines agency issues associated with a company's free cash flows and the use of debt as one means of addressing these issues.

9

Shareholding ministers and their SOE policies may change whenever the political party, or coalition, holding executive government power changes. Control of executive government is contested at least every three years.

${ }^{10}$ Moe (1991) and Hom (1995) discuss how political institutions are designed party for performance and partly for protection against political uncertainty, but often at a cost to the performance goals.

"We accept value maximisation through time as a proxy test for achieving both productive and dynamic efficiency, and as consistent with allocative efficiency where an SOE's product market is subject to either significant competition or an effective regulatory regime.
} 
assets that are not critical to the business; and limiting the level of equity to constrain the company's ability to broaden its scope or scale.

This constraint may impose opportunity costs on SOEs by preventing them from undertaking value-adding projects that could take advantage of economies of scale or scope. It is not likely to impose costs on the wider economy, however, if other firms can undertake these projects at the same or lesser incremental cost. Other firms could be expected to do so, except where an SOE holds a unique set of assets or capabilities relevant to the project. ${ }^{13}$ Such uniqueness is most likely to exist where an SOE has a natural monopoly, such as Trans Power. ${ }^{14}$ In other cases, as the market is able to sustain more than one supplier, other suppliers are likely to have similar assets and capabilities to the $\mathrm{SOE}$, and therefore can be expected to be able to access similar economies of scale or scope.

This focus on core activities has some important implications. First, it may result in SOEs not undertaking value-adding projects otherwise available to them, whereas private investors are likely to undertake them. Second, it means that through time the reported value of an SOE business intentionally may be less than otherwise, and even decrease through time. This may occur, for example, if an SOE does not expand its core business, sheds non-core activities, and returns its excess capital to shareholders. Third, it is likely to mean that the type of skills required for directing and managing an SOE may change — with a greater emphasis on people skilled in generating maximum value from a company that is not taking up investment opportunities as ordinarily would be the case. ${ }^{15}$ Fourth, where an SOE is a dominant player in its product markets, public awareness of the constraints on its future expansion or diversification options may lower entry barriers for its potential competitors. 16 Lower barriers would result from the constraint on scope and scale, reducing the extent to which an SOE could engage in deterrent behaviour and improving allocative efficiency.

\section{2}

This approach, which focuses on incremental costs, assumes SOEs and privately owned firms face the same conditions in other dimensions of the project (such as the same output prices). In practice, market conditions are likely to change through time, which raises dynamic efficiency concerns as to the relative abilities of different firms to adapt and take advantage of new opportunities. It seems reasonable to expect privately owned firms to be at least as efficient in a dynamic sense as an SOE, as they are likely to have stronger incentives to adapt.

13

Uniqueness in this case refers to any assets or capabilities that the SOE holds that provide it with a significant comparative advantage in relation to the particular project.

${ }^{14}$ Where an SOE has a unique set of assets or capabilities, any constraint on its scale or scope may impose costs on the wider economy (if other firms incur greater economic costs than the SOE would in undertaking the project). These costs could be ameliorated by other firms gaining access to these unique assets or capabilities (for instance, through franchising, leasing, or some other access agreement). If access is impracticable, expanding the scope or scale of the SOE could be appropriate.

${ }^{15}$ A key assumption in this approach is the availability of directors and managers that are capable and willing to work to this objective.

${ }^{16}$ The investment constraints placed on ECNZ subsequent to the formation of Contact Energy are an example of this. 
In New Zealand the means of implementing this strategy already exist. The State Owned Enterprises Act, for example, provides mechanisms for shareholding ministers to influence the size and scope of an SOE's business, most notably the SCI that must be negotiated each year between an SOE board and the shareholders.

Operating structure changes. A second means of focusing an SOE on its core value-adding activities is to consider alternative ways of structuring its operating arrangements. The key boundary here is that between relying on the SOE's internal governance rules for decision making and contract enforcement, and relying on external market mechanisms. Options include: management contracting, franchising, contracting out, and leasing out. These options have the effect of altering the boundary of the company, and can be viewed as withdrawing from direct involvement in various parts of the value chain of a business. In the extreme, an SOE could become a shell (or virtual) company, with its primary function being limited to managing a set of contracts (buying not making).

The suitability of the following possible operating structure options will depend on an SOE's circumstances.

- Management contracting entails hiring an outside firm to manage some discrete part of a company's operations or to exercise operational control over the entire operations. It would mean devolving some rights to the contractor in return for various benefits such as access to specialist competencies.

- Franchising involves leasing out the right to use a clearly identifiable 'brand name' or other intellectual property owned by the SOE. This enhances unit managers' incentives to control costs as they have a direct stake in its profits.

- Contracting out means buying some of the goods and services needed to produce finished goods from an outside company. The benefits come from the greater use of competitive-market pressures.

- Leasing out entails transferring some of the rights of ownership to a lessee for a specified period. It could be used when the government is willing to devolve control of a portion of a business into the hands of someone who can operate it more efficiently.

These options may improve efficiency in one or more of the following ways: by shifting some of the residual claimancy rights and obligations outside the company, as a means of overcoming the limitations of the SOE governance arrangements; by harnessing the benefits of competitive markets for intermediate products or services; and/or benefiting from stronger incentives to produce outputs at least cost, by

\footnotetext{
${ }^{17}$ The nature, implications and suitability conditions for each option that is discussed in this section are analysed in generic terms by Brumby, Hyndman and Jamie (1996:34-58).
} 
shifting some strategic and/or management control to parties that typically have stronger incentives to minimise costs.

\section{Strengthening Financial Disciplines}

The capital structure of a company determines the nature of the claims on a company's cash flows and the company's financial flexibility. ${ }^{18}$ In the two polar cases, debt financing commits a company to specified servicing costs (in cash), whereas equity financing provides the company with greater financial discretion. There is a range of intermediate financial instruments. Empirical evidence suggests there is a range of debt:equity ratios over which a particular company's cost of capital is minimised, allowing some latitude in the mix of debt and equity without significantly altering its overall cost of capital.

A degree of financial flexibility is necessary to enable a company to accommodate downside deviations from its business plan without major disruption to its operations or undermining its market position. However, excess flexibility can be costly, particularly where equity capital disciplines are weak, to the extent that it: reduces external discipline on managers to control costs; increases the likelihood that management will invest in projects that do not at least return their cost of capital (that is, projects that erode company value); and signals to potential new entrants the possibility that the SOE has the financial ability to deter potential competitors from entering its market.

Most SOEs typically have had relatively large free cash flows after meeting all costs, including debt obligations, but before paying dividends. These free cash flows have been, and remain, the primary source of SOE expansion; they also reduce the discipline on management to maintain and enhance company value.

Reducing the level of these free cash flows by paying them out to the suppliers of capital could be achieved in two ways: substituting private ${ }^{20}$ debt for government equity, and/or raising dividend levels. Either option would strengthen financial disciplines on an SOE, and could be expected to lead to more efficient use of capital. $^{21}$ Substituting private debt for equity would raise the requirement on SOEs to meet their capital costs in cash, and thereby reduce the cash pool available for use at the discretion of a board. This would place greater discipline on managers to control costs and only take on those projects which return at least their cost of capital.

\footnotetext{
18

Financial flexibility refers to the ability to meet obligations at short notice and reasonable cost under a range of financial market circumstances.

19

See Jensen $(1986,1993)$ and Williamson (1988) for an analysis of the governance implications of corporate capital structure.

20

Private debt is recommended as the government does not appear to have a comparative advantage in supplying debt capital to SOEs. It would also increase the SOE's exposure to another source of monitoring and potential pressure to perform efficiently. 21

The 1997 Budget speech (Peters, 1997:9), for example, indicated that shareholding ministers would be asking SOEs to adjust their capital structures to achieve a debtequity ratio in line with that of comparable private sector businesses.
} 
It may also strengthen the incentives on the debt holders to monitor the SOEs. Raising dividend levels would raise the requirement on SOEs to meet their remaining equity cost of capital in cash, thereby reducing their access to cash reserves.

\section{Managing the Relationship between SOEs and Government}

Continued government ownership of SOEs raises the issue of how the relationship between government and the SOE should be managed. Managing this relationship warrants close attention in the absence of the salutary impact of capital market pressures that privately owned businesses typically face. In New Zealand this relationship is prescribed in broad terms by the State Owned Enterprises Act 1986. This section explores various aspects of the relationship within that context.

Clarifying and communicating the government's intentions. At present, SOEs and the shareholding ministers (and their advisers) tend to debate issues about the capital structure and scope of an SOE's business case by case. The focus of such debates is usually on implications for the SOE's value. Discussion of the issues, and any ensuing decisions, would be better informed if the shareholding ministers were both to articulate their medium-term preferences and expectations, and to communicate them to the interested parties. A public commitment to clearly stated expectations would enhance their credibility by raising the cost to the shareholders of deviating from them. A possible means for achieving this would be for the shareholders to issue a statement of shareholder expectations (SSE). Such a statement would apply to SOE policy some of the principles already adopted in relation to fiscal policy through the Fiscal Responsibility Act.

If the shareholding ministers were to signal to each SOE that it should focus on its core activities and pay out more of its free cash flows, they would also need to communicate clearly that the value of the government's equity in the SOE may decrease over time. This would encourage SOE management to concentrate on the task at hand, rather than seeking out value-adding projects in related (but not core) areas of business.

In summary, providing greater certainty and clarity to an SOE's board and management about its shareholders' expectations and preferences, and about the higher costs to shareholders if they deviate from a publicly committed direction, should improve the efficiency of SOE governance arrangements. More particularly, it could be expected to facilitate management of SOEs within clear parameters that are aligned with the preferences of the shareholders.

\footnotetext{
${ }^{22}$ Any strengthening would depend on debt holders having some concern that the government would not meet all their costs in the event of financial distress, that is to say, that any implicit government guarantee was not complete.

23

This approach would make the contract between shareholders and the SOE more 'complete'. See Hart (1993) and Aghion and Bolton (1992) for a discussion of incomplete contracting issues.

24

For an explanation of this legislation, see New Zealand Treasury (1996).
} 
Monitoring and value-based reporting. The relative lack of capital-market related pressure on SOEs means that the shareholding ministers need to rely on administrative monitoring procedures to hold SOE boards accountable. Current practice includes setting expected financial performance targets in the SCI for the future three years, and reporting against those targets at quarterly, half-yearly and full-year intervals. Boards are required to explain significant deviations from expected financial performance targets. In addition, each SOE may be subject to a business review at periodic intervals, normally no more frequent than every five years. Such monitoring provides a suitable basis for the shareholding ministers to consider the future direction of the company and any changes that may be required.

This monitoring is basically reactive and focused on published $e x$ post financial performance measures.

The absence of capital market disciplines to help align the interests of SOE shareholders and their agents (boards and management) forces greater reliance on in-house performance monitoring. Setting clear goals for $\mathrm{SOE}$ boards to achieve, and strengthening incentives for them to do so (consistent with the SSE), is one form of such monitoring.

The general adoption of value-based reporting (VBR) by SOEs would enhance shareholding ministers' ability to assess the extent to which an SOE is creating or eroding value. VBR involves a company reporting its economic returns, the opportunity cost of the capital used to produce those returns, and the extent to which its various activities add to or reduce its value. ${ }^{25}$ It is a very useful tool that the shareholding ministers could use both to set performance targets and to measure performance, in a way that takes account of the opportunity cost of the equity capital involved.

Director appointments and performance. An SOE's board of directors has a crucial role in maintaining and improving the company's performance. From the government's viewpoint, therefore, it is important both to obtain sufficient suitably skilled directors to oversee these companies, and to ensure that each board of directors has strong incentives to enhance a company's value. This is not a small task: there are about 90 SOE directors, and some 350 directors of all Crown-owned companies.

The following measures could help the government to secure the best performance from its SOE directors.

- Ensuring independence and objectivity in the selection process. This needs to involve selecting SOE directors on the basis of systematically matching candidates' skills and experience to meet a particular set of job specifications tailored (as necessary) to suit a particular SOE.

${ }^{25}$ See Rappaport (1986) and Stewart (1991) for a comprehensive explanation of VBR. 
- Clearly specifying the equity holders' expectations of directors. This could be achieved by the equity holders providing clear terms of reference for individual directors when they are appointed, and each board as a whole through the proposed SSE.

- Strengthening directors' incentives to ensure the company performs well. Directors' incentives could be strengthened by introducing performancerelated rewards and sanctions, and enhancing accountability mechanisms (including shareholder monitoring of the SOE, and VBR). This should include re-appointment being contingent on good performance (given factors within the board's direct sphere of influence), thus preserving the value of reputation.

\section{Conclusions}

In New Zealand a significant number of SOEs have now been privatised. For those SOEs that remain government owned (and where privatisation is ruled out), the important issue of how best to govern them remains. This article has outlined a set of measures that, if adopted, would both limit exposure to the problem of SOEs' inherently weak governance structure, and strengthen incentives for SOEs to perform where the exposure remains.

Aspects of this approach to strengthening the governance of SOEs may be able to be extended to the government's wider ownership interests, for example to its investments in housing, financial services, health and education.

\section{References}

Aghion, P \& P. Bolton (1992), 'An Incomplete Contracts Approach To Financial Contracting', Review of Economic Studies 59: 473-94.

Brumby, J., M. Hyndman \& J. Jamic (1996), 'Crown Company Structure Options', unpublished New Zealand Treasury Staff Working Paper (June).

Domberger, S. \& J. Piggott (1994), 'Privatisation Policies And Public Enterprise: A Survey', pp. 32-61 in M. Bishop. J. Kay \& C. Mayer (eds), Privatisation and Economic Performance, Oxford University Press, Oxford.

Galal, A., L. Jones, P. Tandon, \& I. Vogelsang (1994), Welfare Consequences of Selling Public Enterprises: An Empinical Analysis, Oxford University Press for the World Bank, Oxford and New York

Hart, O. (1995) Firms, Contracts And Financial Structure, Clarendon Press, Oxford.

Hom, M. (1995), The Political Economy of Public Administration: Institutional Choice in the Public Sector, Cambridge University Press, Cambridge.

Jensen, M. (1986), 'Agency Costs of Free Cash Flow, Corporate Finance, and Takeovers', American Economic Review 76: 323-9. 
- (1993), 'The Modern Industrial Revolution, Exit, and the Failure of Internal Control Systems', Journal of Finance 48: 831-80.

Megginson, W., R. Nash, \& M. van Randenborgh (1994), "The Financial and Operating Performance of Newly Privatised Firms: An International Empirical Analysis', Journal of Finance 49: 403-52.

Moe, T. (1991), 'Politics and the Theory of Organisation', Journal of Law, Economics and Organisation 7 (special issue): 106-29.

New Zealand Treasury (1996), Fiscal Responsibility Act 1994: An Explanation, GP Print Limited, Wellington

Peters, Hon. W. (1997), Budget Speech and Fiscal Strategy Report 1997, GP Print Limited, Wellington.

Rappaport, A. (1986), Creating Shareholder Value: The New Standard for Business Performance, Free Press, New York.

Stewart, G. (1991), The Quest for Value: A Guide for Senior Managers, Harper Collins, New York.

Vickers, J. \& G. Yarrow (1991), 'Economic Perspectives on Privatisation', Journal of Economic Perspectives 5(2): 111-32.

Vining, A. \& A. Boardman (1992), 'Ownership versus Competition: Efficiency in Public Enterprise', Public Choice 73: 205-39.

Williamson, O. (1988), 'Corporate Finance and Corporate Governance', Journal of Finance 43(3): $567-91$.

World Bank (1996), World Development Report 1996: From Plan To Market, Oxford University Press, New York.

We are grateful to David Greig of the Victorian Treasury, David Skilling of the New Zealand Treasury, and two anonymous referees for their helpful comments on an earlier draft. 